\title{
Gambaran Hematologic Scoring System pada Tersangka Sepsis Neonatorum
}

\author{
Nur'izzati ${ }^{1}$, Hanifah Maani², Husni²
}

\begin{abstract}
Abstrak
Sepsis neonatorum merupakan penyebab utama morbiditas dan mortalitas neonatus di negara berkembang. Baku emasnya adalah kultur darah, namun sulit dilakukan. Pemeriksaan hematologi sederhana diperlukan untuk membantu klinisi menegakkan diagnosis sepsis neonatorum. Hematologic Scoring System (HSS) memiliki keunggulan terutama kemudahan dan kemurahannya. Tujuan penelitian untuk mengetahui gambaran HSS pada tersangka sepsis neonatorum. Penelitian ini merupakan penelitian deskriptif dengan rancangan potong lintang pada 34 pasien dengan diagnosis tersangka sepsis neonatorum awitan dini. Penelitian dilaksanakan mulai Desember 2015 hingga September 2016. Masing-masing parameter dalam skor HSS diperoleh dari pemeriksaan dengan alat hematologi otomatis dan sediaan hapus darah tepi. Hasil penelitian disajikan dalam bentuk tabel distribusi frekuensi. Tersangka sepsis neonatorum lebih banyak bayi laki-laki $(58,8 \%)$, bayi berat badan lahir rendah $(61,8 \%)$, dan bayi kurang bulan $(64,7 \%)$. Sebanyak 14 pasien $(41,2 \%)$ memiliki skor HSS $\leq 2$ (bukan sepsis), 11 pasien (32,3\%) dengan skor 3-4 (diduga sepsis), dan 9 pasien $(26,5 \%$ ) dengan skor $\geq 5$ (sepsis). Skor terbanyak diperoleh dari peningkatan jumlah PMN dan penurunan jumlah trombosit, yaitu masing-masing $64,7 \%$ dan $50 \%$. Pada skor HSS $\leq 2$ tidak ditemukan peningkatan jumlah PMN imatur serta perubahan degeneratif sitoplasma PMN, sedangkan peningkatan jumlah PMN imatur dan rasio I:T ditemukan pada seluruh sampel dengan skor HSS $\geq 5$. Sebagian besar pasien tersangka sepsis neonatorum memiliki skor HSS $\leq 2$. Skor terbanyak diperoleh dari peningkatan jumlah PMN dan penurunan jumlah trombosit. Penelitian lebih lanjut diperlukan untuk membandingkan HSS dengan baku emas atau penanda sepsis lainnya.
\end{abstract}

Kata kunci: Tersangka sepsis neonatorum, hematologic scoring system

\begin{abstract}
Neonatal sepsis continues to be a major cause of morbidity and mortality in developing countries. Blood culture remains to be the gold standard, but it is difficult in practice. A simple hematologic examination is needed to help clinician diagnosing the disease. Hematologic Scoring System (HSS) is preferable in diagnosing neonatal sepsis because it is simple and inexpensive. The aim of this study was to assess the HSS in suspected neonatal sepsis. This was a descriptive study with cross-sectional design to 34 suspected early onset neonatal sepsis. This study was conducted from December 2015 until September 2016. Each HSS parameters was analyzed by using hematology analyzer and peripheral blood smear. Data was presented in the frequency distribution tables. Male neonates, low birth-weight infants, and preterm infants were predominant, they are $58.8 \%, 61.8 \%$, and $64.7 \%$ respectively. There were 14 (41.2\%) patients with HSS score was $\leq 2$ (sepsis unlikely), 11 (32.3\%) patients with HSS score was 3-4 (possible sepsis), and 9 (26.5\%) patients with HSS score $\geq 5$ (very likely sepsis). The elevation of total polimorphonuclear (PMN) count and the decrease of platelet count were more frequent among all patients, which was $64.7 \%$ and $50 \%$. There was no elevation of immature $P M N$ count and degenerative changes of PMN cytoplasm in patients with HSS score was $\leq 2$, while the elevation of immature PMN count and I:T ratio were found in all of the patients with HSS score was $>5$. Most of suspected neonatal sepsis patients had score $\leq 2$. The elevation of total PMN count and the decrease of platelet count were more frequent among all patients. Further study is needed to review the HSS with the gold standard or other sepsis markers.
\end{abstract}

Keywords: Suspected neonatal sepsis, hematologic scoring system

Affiliasi penulis : 1. Program Pendidikan Dokter Spesialis Patologi Klinik Fakultas Kedokteran Universitas Andalas/ Rumah Sakit Umum Pusat Dr. M. Djamil, Padang; 2. Bagian Patologi Klinik Fakultas Kedokteran Universitas Andalas/ Rumah Sakit Umum Pusat Dr. M. Djamil, Padang

Korespondensi: JI.Perintis Kemerdekaan Padang; Email: pdspatklin pdg@yahoo.com; Telp.(0751) 841514

\section{PENDAHULUAN}

Sepsis neonatorum merupakan respons neonatus terhadap infeksi pada bulan pertama kehidupan. Sepsis neonatorum merupakan penyebab utama morbiditas dan mortalitas neonatus di negara berkembang, namun dapat disembuhkan jika terdiagnosis dan ditatalaksana secara cepat dan tepat. ${ }^{1}$ Empat juta bayi meninggal setiap tahunnya pada periode neonatus dan $99 \%$ kasus terdapat di negara berkembang. Survei Demografi dan Kesehatan Indonesia tahun 2007 melaporkan bahwa angka kematian neonatus akibat sepsis neonatorum adalah 19 per 1000 kelahiran hidup..$^{2,3,4}$

Insidensi sepsis neonatorum meningkat pada bayi berat badan lahir sangat rendah ( $<1000$ gram) yaitu 26 per 1000 kelahiran hidup, dan 8-9 per 1000 kelahiran hidup pada bayi berat badan lahir rendah (1000-2000 gram). Bayi kulit hitam dan laki-laki lebih berisiko terhadap sepsis neonatorum. ${ }^{5}$ 
Sepsis neonatorum dapat diklasifikasikan menjadi dua, yaitu sepsis awitan dini (early onset sepsis) dan sepsis awitan lambat (late onset sepsis). Sepsis awitan dini terjadi $<72$ jam segera pascanatal dan berhubungan dengan demam intrapartum, amnionitis, ketuban pecah dini, dan bayi preterm, dengan tanda distress pernafasan yang lebih mencolok. Penyebab terbanyak sepsis adalah bakteri. Bakteremia dapat menimbulkan keadaan yang berlanjut mulai dari infeksi menjadi SIRS, kemudian terjadi sepsis, sepsis berat, syok sepsis, dan akhirnya dapat menyebabkan multiple organ dysfunction syndrome. ${ }^{6,7}$

Baku emas diagnosis sepsis neonatorum adalah kultur darah, namun pemeriksaan ini memiliki beberapa kelemahan, diantaranya memerlukan waktu yang relatif lama yaitu 2-3 hari, rendahnya tingkat positivitas, dan ketiadaan fasilitas di beberapa laboratorium. $8,9,10$ Pemeriksaan hematologi sederhana diperlukan untuk membantu klinisi menegakkan diagnosis sepsis neonatorum.

Sistem skoring berdasarkan beberapa hasil pemeriksaan hematologi pertama kali digunakan oleh Rodell et al., yang dikenal dengan istilah hematologic scoring system (HSS). Hematologic Scoring System merupakan suatu pemeriksaan hematologi dengan melihat tujuh parameter hematologi yang dapat memprediksi sepsis neonatorum. Sistem skoring ini dapat dipakai pada sepsis neonatorum awitan dini dan awitan lambat. Semakin besar jumlah skor maka kemungkinan terjadinya sepsis juga meningkat. ${ }^{3}$

Hematologic Scoring System memiliki keunggulan terutama dalam kemudahan dan kemurahannya. Pemeriksaan ini mudah dilakukan dan sederhana serta hasil pemeriksaannya tidak membutuhkan waktu yang lama Sistem skoring ini dapat membantu klinisi untuk menentukan diagnosis, menurunkan angka kematian, dan melaksanakan pendekatan rasional terhadap pengobatan pasien seperti menghindari penggunaan antibiotik yang tidak rasional sehingga dapat mencegah terjadinya resistensi kuman terhadap antibiotik. ${ }^{11}$

Penelitian ini bertujuan untuk mengetahui gambaran HSS pada pasien tersangka sepsis neonatorum di laboratorium 24 jam RSUP Dr. M. Djamil Padang.

\section{METODE}

Penelitian ini adalah suatu penelitian deskriptif dengan rancangan potong lintang yang dilakukan di laboratorium 24 jam RSUP Dr. M. Djamil Padang pada bulan Desember 2015 sampai dengan September 2016. Populasi penelitian adalah seluruh pasien dengan diagnosis kerja tersangka sepsis neonatorum awitan dini yang dilakukan pemeriksaan hematologi. Pada penelitian ini didapatkan 34 sampel yang memenuhi kriteria inklusi dan eksklusi. Sampel yang diikutsertakan dalam penelitian mendapat izin dari orang tua/ wali serta bersedia menandatangani informed consent.
Bahan pemeriksaan adalah darah vena $0,5 \mathrm{~mL}$ dalam tabung dengan antikoagulan EDTA neonatus. Darah diambil pertama kali ketika pasien datang ke Instalasi Gawat Darurat (IGD) dan pada bayi yang dirawat di ruang perinatologi RSUP Dr. M. Djamil Padang.

Parameter skor HSS yang dinilai dapat dilihat pada tabel 1. Terdapat 7 parameter yang masing-masing diberi skor 1 kecuali pada hitung absolut polimorfonuklear (PMN) yang tidak ada PMN matur (diberi skor 2). Apabila semua parameter ditemukan maka skor total adalah 7. Jumlah skor $\leq 2$ diinterpretasikan sebagai bukan sepsis, skor 3-4 diduga sepsis, dan skor $\geq 5$ sepsis. ${ }^{11}$

Tabel 1. Parameter hematologi pada $\mathrm{HSS}^{11}$

\begin{tabular}{|c|c|c|}
\hline Kriteria & Abnormalitas & Skor \\
\hline Jumlah & $\leq 5000 / \mu \mathrm{L}$ & 1 \\
\hline \multirow[t]{3}{*}{ Leukosit } & $\geq 25000 / \mu \mathrm{L}$ saat lahir & 1 \\
\hline & $\begin{array}{l}\geq 30000 / \mu \mathrm{L} \text { pada umur } 12- \\
24 \mathrm{jam}\end{array}$ & 1 \\
\hline & $\begin{array}{l}\geq 21000 / \mu \mathrm{L} \text { umur } 2 \text { hari ke } \\
\text { atas }\end{array}$ & 1 \\
\hline \multirow[t]{3}{*}{ Total PMN ${ }^{*}$} & $1800-5400 / \mu \mathrm{L}$ & 0 \\
\hline & Tidak ada PMN matur & 2 \\
\hline & Meningkat atau menurun & 1 \\
\hline Imatur & $600 / \mu \mathrm{L}$ & 0 \\
\hline $\mathrm{PMN}^{\star \star}$ & Meningkat & 1 \\
\hline Rasio I : $\mathrm{T}$ & 0,120 & 0 \\
\hline $\mathrm{PMN}^{\star \star \star}$ & Meningkat & 1 \\
\hline Rasio I : M & $<0,3$ & 0 \\
\hline$P M^{\star \star \star \star}$ & $\geq 0,3$ & 1 \\
\hline $\begin{array}{l}\text { Perubahan } \\
\text { degeneratif } \\
\text { PMN }\end{array}$ & $\begin{array}{l}\text { Granulasi toksik/ } \\
\text { vakuolisasi sitoplasma }\end{array}$ & 1 \\
\hline $\begin{array}{l}\text { Jumlah } \\
\text { Trombosit }\end{array}$ & $\leq 150000 / \mu \mathrm{L}$ & 1 \\
\hline
\end{tabular}

Jumlah leukosit dan trombosit diperiksa dengan alat hematologi otomatis dengan metode impedans. Prosedur quality control dilakukan setiap hari sebelum alat digunakan. Jumlah PMN matur dan imatur dan perubahan degeneratif pada sitoplasma neutrofil dilakukan manual dengan melihat sediaan hapus darah tepi menggunakan mikroskop cahaya dengan pembesaran lensa objektif 100x.

Pemeriksaan sediaan hapus darah tepi dilakukan oleh dua orang yang memiliki kompetensi dan masingmasing tidak mengetahui hasil pembacaan sediaan satu dengan yang lainnya. Pemeriksaan dilakukan dengan terlebih dahulu menyesuaikan interpretasi pengertian bentuk dan morfologi sel-sel darah terutama sel neutrofil matur dan imatur antar pembaca dengan mengacu pada buku atlas hematologi.

Data diolah secara manual dan ditampilkan dalam bentuk tabel distribusi frekuensi.

\section{HASIL DAN PEMBAHASAN}

Dari 34 sampel penelitian didapatkan distribusi karakteristik pada tabel 2 sebagai berikut: 
Tabel 2. Distribusi karakteristik subjek penelitian

\begin{tabular}{|c|c|c|}
\hline Karakteristik & Jumlah & $\%$ \\
\hline \multicolumn{3}{|l|}{ Jenis kelamin } \\
\hline - Laki-laki & 20 & 58,8 \\
\hline - Perempuan & 14 & 41,2 \\
\hline \multicolumn{3}{|l|}{ Berat badan lahir } \\
\hline - $\quad<2500$ gram & 21 & 61,8 \\
\hline - $\geq 2500 \mathrm{gram}$ & 13 & 38,2 \\
\hline \multicolumn{3}{|l|}{ Usia kehamilan } \\
\hline - $\quad<37$ minggu & 22 & 64,7 \\
\hline - $>37$ minggu & 12 & 35,3 \\
\hline
\end{tabular}

Penelitian ini mendapatkan tersangka sepsis neonatorum awitan dini lebih banyak terjadi pada bayi laki-laki dibandingkan dengan perempuan (berturutturut $58,8 \%$ dan $41,2 \%$ ). Secara epidemiologi sepsis neonatorum lebih banyak terjadi pada laki-laki dibandingkan perempuan. Hal tersebut berhubungan dengan faktor pertahanan tubuh yang bersifat $X$-linked. MikroRNA yang terdapat di dalam kromosom $X$ adalah suatu molekul yang meregulasi protein yang dibutuhkan untuk sistem imunitas. Bayi perempuan memiliki 2 kromosom $X(X X)$, sedangkan bayi laki-laki memiliki satu kromosom $X$ dan satu kromosom $Y(X Y)$. Dengan demikian bayi perempuan memiliki mikroRNA lebih banyak sehingga bayi perempuan memiliki fungsi pertahanan tubuh terhadap infeksi lebih besar dibandingkan laki-laki. ${ }^{12,13}$

Penelitian lain mendapatkan perbedaan jumlah yang tidak bermakna antara kejadian sepsis neonatorum pada bayi laki-laki dan perempuan. Penelitian tersebut mendapatkan sepsis neonatorum pada bayi laki-laki lebih banyak dibandingkan dengan perempuan pada skor HSS $\geq 3$, sedangkan pada skor $\leq 2$ didapatkan jumlah bayi perempuan lebih banyak. Namun secara keseluruhan jumlah bayi perempuan lebih banyak dibandingkan laki-laki. ${ }^{11}$

Tersangka sepsis awitan dini lebih banyak terjadi pada bayi dengan berat badan lahir $<2500$ gram dibandingkan dengan bayi dengan berat badan lahir $\geq 2500$ gram (berturut-turut $61,8 \%$ dan $38,2 \%$ ). Berdasarkan usia kehamilan didapatkan $64,7 \%$ tersangka sepsis neonatorum merupakan bayi kurang bulan, sisanya merupakan bayi cukup bulan (35,3\%).

Beberapa penelitian sebelumnya menemukan sepsis neonatorum lebih banyak terjadi pada bayi dengan berat badan lahir rendah. Usia kehamilan merupakan indikasi kesejahteraan bayi baru lahir karena semakin cukup usia kehamilan semakin baik kesejahteraan bayi. Hubungan antara berat lahir dan usia kehamilan mencerminkan kecukupan pertumbuhan intrauterin dan dapat membantu memprediksi masalah klinis pada usia neonatus. ${ }^{11,12}$ Gangguan pertumbuhan intrauterin dapat memengaruhi berat lahir dan perkembangan sistem pernafasan, kardiovaskular, neurologis, hematologis, dan imunologis. Gangguan perkembangan sistem imun meningkatkan risiko infeksi. Bayi kurang bulan (usia kehamilan <37 minggu) memiliki fungsi sistem imun yang belum matang sehingga proses fagositosis sebagai pertahanan tubuh terhadap infeksi terganggu. ${ }^{12}$ Bayi kurang bulan dan bayi dengan berat badan lahir rendah lebih rentan terhadap infeksi karena mekanisme pertahanan tubuh yang masih rendah dan sistem imun yang belum sempurna. ${ }^{13}$

Secara keseluruhan didapatkan distribusi skor HSS pada pasien tersangka sepsis neonatorum awitan dini dapat dilihat pada tabel 3:

Tabel 3. Skor HSS pada tersangka sepsis neonatorum

\begin{tabular}{lll}
\hline \multicolumn{1}{c}{ Skor HSS } & Jumlah & $\%$ \\
\hline$\leq 2$ (bukan sepsis) & 14 & 41,2 \\
$3-4$ (diduga sepsis) & 11 & 32,3 \\
$\geq 5$ (sepsis) & 9 & 26,5 \\
\hline
\end{tabular}

Dari 34 sampel tersangka sepsis neonatorum didapatkan 14 pasien $(41,2 \%)$ dengan skor HSS $\leq 2$ (bukan sepsis), 11 pasien (32,3\%) dengan skor $3-4$ (diduga sepsis), dan 9 pasien (26,5\%) dengan skor $\geq 5$ (sepsis). Sebagian besar pasien tersangka sepsis neonatorum adalah bukan sepsis menurut kriteria skor HSS. Hal ini disebabkan terdapatnya beberapa sampel dengan keterangan klinis risiko infeksi dimana bayi dikatakan tersangka sepsis karena terdapatnya beberapa faktor risiko, di antaranya bayi prematur dan berat badan lahir rendah, ketuban pecah dini $>18$ jam, ibu demam peripartum atau ibu dengan infeksi, cairan ketuban hijau dan berbau, tindakan resusitasi pada bayi baru lahir, kehamilan kembar, dan lain-lain. ${ }^{7}$ Beberapa faktor risiko tersebut ditemukan pada beberapa neonatus ataupun ibu namun manifestasi klinis sepsis tidak begitu tampak.

Tabel 4 memperlihatkan secara keseluruhan jumlah masing-masing parameter HSS yang dinilai dalam penelitian ini. Dari 34 pasien tersangka sepsis neonatorum didapatkan skor yang terbanyak adalah peningkatan jumlah absolut PMN dan penurunan jumlah trombosit, yaitu masing-masing $22(64,7 \%)$ dan 17 (50\%). Pada skor HSS $\leq 2$ tidak ditemukan peningkatan jumlah $\mathrm{PMN}$ imatur, peningkatan rasio neutrofil imatur dan neutrofil total, peningkatan rasio neutrofil imatur dan matur, serta perubahan degeneratif pada sitoplasma neutrofil; sedangkan peningkatan jumlah neutrofil imatur dan peningkatan rasio neutrofil imatur dan neutrofil total ditemukan pada seluruh sampel dengan skor HSS $\geq 5$.

Tabel 5 menggambarkan distribusi masing-masing parameter skor HSS pada pasien dengan skor $<2$ (bukan sepsis), 3-4 (diduga sepsis), dan $\geq 5$ (sepsis). Pada kelompok pasien dengan skor $\leq 2$ peningkatan julmlah absolut PMN didapatkan pada 6 pasien $(42,9 \%)$, tidak didapatkan peningkatan jumlah PMN imatur serta peningkatan rasio I:T maupun I:M. Pada kelompok ini juga tidak didapatkan perubahan degeneratif pada sitoplasma neutrofil. Penurunan jumlah trombosit didapatkan pada 2 pasien (14,3\%). 
Tabel 4. Skor masing-masing parameter HSS secara keseluruhan

\begin{tabular}{|c|c|c|c|c|c|c|c|c|c|c|c|c|c|c|}
\hline \multirow[t]{2}{*}{ HSS } & \multicolumn{2}{|c|}{$\begin{array}{l}\text { Jumlah } \\
\text { leukosit }\end{array}$} & \multicolumn{2}{|c|}{$\begin{array}{l}\text { Jumlah } \\
\text { PMN }\end{array}$} & \multicolumn{2}{|c|}{$\begin{array}{l}\text { Jumlah } \\
\text { PMN } \\
\text { Imatur }\end{array}$} & \multicolumn{2}{|c|}{$\begin{array}{l}\text { Rasio PMN } \\
\text { I:T }\end{array}$} & \multicolumn{2}{|c|}{$\begin{array}{l}\text { Rasio } \\
\text { PMN I:M }\end{array}$} & \multicolumn{2}{|c|}{$\begin{array}{l}\text { Perubahan } \\
\text { degeneratif } \\
\text { sitoplasma } \\
\text { neutrofil }\end{array}$} & \multicolumn{2}{|c|}{$\begin{array}{l}\text { Jumlah } \\
\text { trombosit }\end{array}$} \\
\hline & 0 & 1 & 0 & 1 & 0 & 1 & 0 & 1 & 0 & 1 & 0 & 1 & 0 & 1 \\
\hline$\leq 2$ & 13 & 1 & 8 & 6 & 14 & 0 & 14 & 0 & 14 & 0 & 14 & 0 & 12 & 2 \\
\hline $3-4$ & 9 & 2 & 3 & 8 & 4 & 7 & 4 & 7 & 10 & 1 & 7 & 4 & 3 & 8 \\
\hline$\geq 5$ & 1 & 8 & 1 & 8 & 0 & 9 & 0 & 9 & 3 & 6 & 3 & 6 & 2 & 7 \\
\hline $\begin{array}{l}\text { Total } \\
(\%)\end{array}$ & $\begin{array}{l}23 \\
(67,6)\end{array}$ & $\begin{array}{c}11 \\
(32,4)\end{array}$ & $\begin{array}{c}12 \\
(35,3)\end{array}$ & $\begin{array}{l}22 \\
(64,7)\end{array}$ & $\begin{array}{c}18 \\
(52,9)\end{array}$ & $\begin{array}{c}16 \\
(47,1)\end{array}$ & $\begin{array}{c}18 \\
(52,9)\end{array}$ & $\begin{array}{c}16 \\
(47,1)\end{array}$ & $\begin{array}{c}27 \\
(79,4)\end{array}$ & $\begin{array}{c}7 \\
(20,6)\end{array}$ & $\begin{array}{c}24 \\
(70,6)\end{array}$ & $\begin{array}{c}10 \\
(29,4)\end{array}$ & $\begin{array}{c}17 \\
(50)\end{array}$ & $\begin{array}{c}17 \\
(50)\end{array}$ \\
\hline
\end{tabular}

Tabel 5. Parameter HSS pada skor $\leq 2$

\begin{tabular}{|c|c|c|c|c|}
\hline \multirow{2}{*}{ HSS } & \multicolumn{2}{|c|}{ Nilai 1} & \multicolumn{2}{|c|}{ Nilai 0} \\
\hline & Jumlah & $\%$ & Jumlah & $\%$ \\
\hline \multicolumn{5}{|l|}{ Skor HSS $\leq 2$} \\
\hline - Jumlah leukosit & 1 & 7,1 & 13 & 92,9 \\
\hline - Jumlah absolut PMN & 6 & 42,9 & 8 & 57,1 \\
\hline - Jumlah absolut PMN imatur & 0 & 0 & 14 & 100 \\
\hline - Rasio PMN imatur dan PMN total & 0 & 0 & 14 & 100 \\
\hline - $\quad$ Rasio PMN imatur dan PMN matur & 0 & 0 & 14 & 100 \\
\hline - Perubahan degeneratif neutrofil & 0 & 0 & 14 & 100 \\
\hline - Jumlah trombosit & 2 & 14,3 & 12 & 85,7 \\
\hline \multicolumn{5}{|l|}{ Skor HSS 3-4 } \\
\hline - Jumlah leukosit & 2 & 18,2 & 9 & 81,8 \\
\hline - Jumlah absolut PMN & 8 & 72,7 & 3 & 27,3 \\
\hline - Jumlah absolut PMN imatur & 7 & 63,6 & 4 & 36,4 \\
\hline - Rasio PMN imatur dan PMN total & 7 & 63,6 & 4 & 36,4 \\
\hline - $\quad$ Rasio PMN imatur dan PMN matur & 1 & 9,1 & 10 & 90,9 \\
\hline - $\quad$ Perubahan degeneratif neutrofil & 4 & 36,4 & 7 & 63,6 \\
\hline - Jumlah trombosit & 8 & 72,7 & 3 & 27,3 \\
\hline \multicolumn{5}{|l|}{ Skor HSS $\geq 5$} \\
\hline - Jumlah leukosit & 8 & 88,9 & 1 & 11,1 \\
\hline - Jumlah absolut PMN & 8 & 88,9 & 1 & 11,1 \\
\hline - Jumlah absolut PMN imatur & 9 & 100 & 0 & 0 \\
\hline - Rasio PMN imatur dan PMN total & 9 & 100 & 0 & 0 \\
\hline - $\quad$ Rasio PMN imatur dan PMN matur & 6 & 66,7 & 3 & 33,3 \\
\hline - $\quad$ Perubahan degeneratif neutrofil & 6 & 66,7 & 3 & 33,3 \\
\hline - Jumlah trombosit & 7 & 77,8 & 2 & 22,2 \\
\hline
\end{tabular}

Pada kelompok pasien dengan HSS 3-4 peningkatan jumlah leukosit didapatkan pada 2 pasien $(18,2 \%)$, peningkatan jumlah PMN absolut didapatkan pada 8 pasien $(72,7 \%)$, dan juga didapatkan peningkatan jumlah PMN imatur sampai dengan metamielosit. Pada kelompok ini didapatkan 4 pasien $(36,4 \%)$ dengan perubahan degeneratif pada sitoplasma neutrofil serta 8 pasien $(72,7 \%)$ dengan penurunan jumlah trombosit.

Pada kelompok pasien dengan HSS $\geq 5$ peningkatan jumlah leukosit didapatkan pada 8 pasien $(88,9 \%)$, peningkatan jumlah PMN absolut didapatkan pada 8 pasien $(88,9 \%)$, dan juga didapatkan peningkatan jumlah PMN imatur sampai dengan mielosit. Pada kelompok ini didapatkan 6 pasien $(66,7 \%)$ dengan perubahan degeneratif pada sitoplasma neutrofil serta 7 pasien $(77,8 \%)$ dengan penurunan jumlah trombosit.
Pada infeksi akut terjadi peningkatan pelepasan granulosit matur dari sumsum tulang hingga \pm 50 kali. Pelepasan interleukin (IL)-1, tumor necrosis factor (TNF), dan sitokin inflamasi lainnya merangsang sel stroma sumsum tulang dan sel T untuk meningkatkan produksi colony-stimulating factors (CSFs) sehingga meningkatkan proliferasi dan diferensiasi progenitor granulosit, akibatnya akan terjadi peningkatan produksi neutrofil. ${ }^{14}$

Leukositosis sering diikuti dengan perubahan morfologi leukosit pada infeksi yang berat, seperti granulasi toksik, vakuolisasi sitoplasma, dan adanya Dohle bodies. Granulasi toksik tampak sebagai granul kasar dengan warna lebih tua dari granul neutrofil normal. ${ }^{14}$

Terjadinya penurunan jumlah trombosit disebabkan oleh peningkatan destruksi trombosit, sekuestrasi sekunder terhadap infeksi, serta kegagalan produksi 
trombosit akibat penurunan jumlah megakariosit atau efek perusakan oleh endotoksin. ${ }^{11}$

\section{SIMPULAN}

Sebagian besar pasien tersangka sepsis neonatorum memiliki skor HSS $\leq 2$. Skor terbanyak diperoleh dari peningkatan jumlah PMN dan penurunan jumlah trombosit.

Penelitian lebih lanjut diperlukan untuk membandingkan HSS dengan baku emas atau penanda sepsis lainnya.

\section{DAFTAR PUSTAKA}

1. Manucha V, Rusia U, Sikka M, Faridi MM, Madan N. Utility of Hematological Parameters and Creactive Protein in The Detection of Neonatal Sepsis. J Paediatr Child Health. 2002; 38:459-64.

2. Puopolo KM. Bacterial and Fungal Infections Dalam: Cloherty J, Eichenwald E, Stark A, editor. Manual of Neonatal Care $7^{\text {th }}$ ed. Philadelphia: Lippincott Williams \& Wilkins; 2012. p.624-55.

3. Aminullah A. Sepsis pada Bayi Baru Lahir. Dalam: Kosim MS, Yunanto A, Dewi R, Sarosa GI, Usman A, editor. Buku Ajar Neonatologi. Jakarta: Departemen IImu Kesehatan Anak FKUI-RSCM; 2008. p.1-15.

4. Kemenkes RI. Kondisi Angka Kematian Neonatus $(A K N)$ dan Penyebabnya di Indonesia. Jakarta: Kemenkes RI; 2009.

5. Boseila S, Seoud I, Samy G, Gamal HE, Ibrahim TS, Ahmed A, et al. Serum Neopterin Level in Early Onset Neonatal Sepsis. Journal of American Science. 2004; 7(7):343-50.

6. Golsdtein B, Giroir B, Randolph A. International Pediatric Sepsis Consensus Confrence: definitions for sepsis and organ dysfunction in pediatrics. Pediatr Crit Care Med. 2005; 6(1):2-8.

7. Gomella TL. Neonatal Sepsis. Dalam: Gomela TL, Cunningham MD, Efyal FG, Zenk KE, editor. Neonatology Management Procedures on Call Problems Diseases Drugs. $4^{\text {th }}$ ed. New York: McGrawHill; 2004. p.339-66.

8. Misra PK, Kumar R, Malik GK, Mehra P, Awasthi S. Simple Hematological Tests for Diagnosis of Neonatal Sepsis. Indian Pediatr. 1989; 26:15660.

9. Sharma A, Kutty CV, Sabharwal U, Rathee S, Mohan H. Evaluation of Sepsis Screen for Diagnosis of Neonatal Septicemia. Indian $J$ Pediatr. 1993; 60:559-63.

10. Varsha, Rusia U, Sikka M, Faridi MM, Madan N. Validity of Hematologic Parameters in Identification of Early and Late Onset Neonatal Infection. Indian J Pathol Microbiol. 2003; 46:5658.

11. Makkar M, Gupta C, Pathak R, Garg S, Mahajan NC. Performance Evaluation of Hematologic Scoring System in Early Diagnosis of Neonatal Sepsis. Journal of Clinical Neonatology. 2013; 2:25-9.

12. Iskandar TR, Dalimoenthe NZ, Yuniaty T, Turbawaty DK. Validitas Skoring Hematologi Rodwell untuk Deteksi Dini Sepsis Neontorum Awitan Dini. Sari Pediatri. 2015; 16(5):330-6.

13. Khair KB, Rahman MA, Sultana T, Roy CK, Rahman MQ, Shahidullah $M$, dkk. Role of
Hematologic Scoring System In Early Diagnosis of Neonatal Septicemia. BSMMU J. 2010; 3:62-7.

14. Kumar V, Abbas AK, Aster JC. White Blood Cells and Lymph Nodes. Dalam: Kumar V, Abbas AK, Aster JC, editor. Robbins and Cotran Pathologic Basis of Disease. $7^{\text {th }}$ ed. Philadelphia: Elsevier Saunders; 2005. p.662-5. 